"Енергетика і автоматика", №4, 2019 р.

МЕТОДИКА ВИЗНАЧЕННЯ ЯКІСНИХ ПОКАЗНИКІВ ПРОДУКТІВ ФЕРМЕНТАЦІї БІОГАЗОВИХ УСТАНОВОК

М.В. Потапенко, кандидат технічних наук, стариий викладач В. Ю. Рами, кандидат технічних наук, доцент

В.Л. Шарионь, асистент

ВП НУБіП Украӥни “Бережсанський агротехнічний інститут”

E-mail: m.potapenko@i.ua

Анотація. Підвищення ефективності біогазової установки визначається підбором компонентів за однорідністю і ступенем попереднього їх подрібнення, щзо виливає на кількість одержаного біогазу через тривалість періоду зброджування.

Щоб визначити якісні характеристики продуктів ферментації, застосовано метод відбору проб і виділення з них твердої фракиії.

Технологічний процес отримання біогазу необхідно проводити так, щоб у результаті перемішування субстрату з новою пориією, яка надходить $в$ метантенк, одержати продукт ферментації з оптимальним вмістом дисперсної фази. Частота перемішування буде залежати від швидкості осідання зважених частинок субстрату.

Проведено дослідження з визначення фракиійного складу гноївки. $3 a$ їх результатами встановлено еквівалентний діаметр частинок субстрату. Визначено допустимий відносний вміст дисперсного середовища $m_{\partial}$, при якому навантаження площі зброджування в метантенку буде не менше нижньої межі оптимальності.

Підтримання якісних показників продуктів ферментації в межах оптимальності дозволить підвищити продуктивність метантенка на 10-12 \%. Час, за який відносний вміст дисперсної фази субстрату змінюватиметься від $m_{\text {оп }}$ до $m_{\partial}$, $\epsilon$ часом пауз між ииклами перемімування субстрату, щэо дозволить зменшити затрати енергії на виробництво біогазу.

Ключові слова: анаеробна ферментація, метантенк, біогазова установка, частота перемішування, об'ємна концентрація субстрату

Актуальність. Наявність енергетичної кризи та загострення екологічних проблем обумовили значний інтерес до енергозберігаючих i екологозахисних технологій. Проблема високої енергоємності виробництва ускладняється винятково низьким рівнем використання енергетичних ресурсів. 
Безперечний теоретичний та практичний інтерес викликають питання екологізації промислового та сільськогосподарського виробництва на базі нових енергозберігаючих технологій для зниження техногенного навантаження на навколишнє середовище.

Нині в сільськогосподарському виробництві найбільшим забруднювачем навколишнього середовища є тваринництво. Технологічні схеми, які застосовуються для видалення і використання відходів тваринництва, пов’язані 3 тривалим зберіганням необроблених відходів або 3 вивезенням їх на поля, що шкідливо впливає на оточуюче довкілля та на якість продуктів рослинництва [2].

Найбільш перспективним методом утилізації відходів тваринництва, поряд 3 хімічними та фізичними методами, $€$ метанове зброджування. У процесі зброджування органічні відходи розкладаються 3 утворенням біогазу, який $\epsilon$ альтернативним та екологічно чистим видом палива, та може бути замінником традиційних енергоносіїв, а відходи, застосовуються як високоякісне біодобриво.

Анаеробна переробка органічної маси відбувається в спеціальних комплексах, які називаються біогазовими установками.

Найважливішими факторами, що впливають на продуктивність біогазових установок, є правильний вибір компонентів сировини, з якої одержується біогаз, i грамотна їх підготовка до ферментації.

Застосування біогазових установок дозволяє вирішити проблеми екологічного, енергетичного та агрохімічного характеру, а тому є базовою основою для створення екологічно чистих технологій переробки органічних відходів [4].

Встановлено, що ресурси біомаси в різних видах є в усіх регіонах України, i майже в кожному з них може бути налагоджена їх переробка в енергію й паливо [1].

Аналіз останніх досліджень та публікацій. Біогаз - це горючий газ, який складається в основному з метану (вміст від 50 до 85 \%), вуглекислого газу (вміст від 15 до 50 \%) та інших газів в набагато меншому процентному співвідношенні. Його склад є нестабільним і може змінюватись залежно від типу 
біомаси, мікроорганізмів, що беруть участь у зброджуванні, а також домішок та фізичних чинників впливу на процес.

Анаеробне зброджування органічних відходів 3 отриманням біогазу здійснюється в спеціальних установках, основним елементом яких є метантенк [3].

Утворення біогазу - процес, який проходить у всьому об'ємі метантенка, тому для його інтенсифікації необхідною умовою є перемішування середовища.

Кількість біогазу, який утворюється в метантенку, залежить від кількості перероблюваної за добу продукції, iї якісного складу і температурного режиму ферментації. Для нормальної життєдіяльності анаеробних бактерій необхідно, щоб мінімальний вміст азоту складав 7 мг на 100 кг органічної речовини, а оптимальне співвідношення азот-вуглець знаходилось у межах $0,06 \ldots 0,1$. Тому вміст органічної речовини визначає завантаження площі бродіння, а іï величина залежить від швидкості розкладу та осідання зважених частинок [6].

Підвищення ефективності біогазової установки визначається підбором компонентів за однорідністю і ступенем попереднього їх подрібнення, що впливає на кількість одержаного біогазу через тривалість періоду зброджування.

Оптимальне завантаження площі бродіння в гноївці окремих видів тварин на $1 \mathrm{~m}^{3}$ субстрату становить: корови $-6 \%$, свині - $3 \%$, птиця $-1,5 \%$ [4]. Коли вміст сухої речовини буде меншим 1 \%, то процеси метаноутворення пасивуються, тому підтримання гомогенного середовища в метантенку є обов'язковою умовою, яка виконується шляхом переміщення субстрату.

Проте до цього часу деякі важливі технологічні параметри роботи метантенків розроблені недостатньо. Зокрема, мало досліджена структура продуктів ферментації та швидкість ії зміни в процесі метаноутворення.

Мета дослідження - розроблення методики визначення якісних показників продуктів ферментації, що дозволить підвищити продуктивність роботи біогазових установок. 
Матеріали і методи дослідження. У метантенку протікає анаеробний процес розкладання біомаси під впливом метаногенних бактерій при певній температурі зброджування [7].

Розмір можливого завантаження бродильної камери метантенка залежить в першу чергу від обраної температури і часу зброджування [3].

На вибір форми, розмірів і конструкції метантенка впливає ступінь завантаження робочого простору, час циклу зброджування i інтенсивності перемішування; застосовувана система виробництва; рівень механізації. Ці фактори визначаються умовами виробництва і цілями технологічного процесу.

При періодичній схемі метантенки (мінімум два) завантажують по черзі, при чому свіжий субстрат змішують із залишком збродженого шламу. Біогаз починає утворюватися після закінчення 5-6 доби і при досягненні максимальної кількості поступово знижується до мінімуму. Далі зброджений субстрат вивантажують, і метантенки знову завантажують свіжим субстратом.

Щоб визначити якісні характеристики продуктів ферментації, які будуть задіяні в процесі одержання біогазу, застосовують метод відбору проб і виділення 3 них твердої фракції.

Для здійснення контролю застосовується однократна вибірка, тобто здійснення визначеної заздалегідь фіксованої кількості числа проб, після цього робиться висновок про ступінь відповідності субстрату технічним вимогам.

Результати досліджень та їх обговорення. Структура робочого циклу метантенка повинна бути такою: відбір відстояної верхньої частини субстрату та видалення шламу з нижньої частини, при цьому відносний вміст дисперсного середовища в активній зоні метантенка повинен дорівнювати $m_{\partial}$; заповнення метантенка такою ж кількістю свіжої сировини з відносним вмістом дисперсної фази $m_{6}$.

Технологічний процес отримання біогазу потрібно проводити так, щоб в результаті перемішування субстрату з новою порцією, яка надходить в метантенк, 
одержати продукт ферментації 3 оптимальним вмістом дисперсної фази $m_{o n}$. Підтримуючи гомогенне середовище в метантенку під час циклу бродіння, після якого здійснюється відбір верхньої частини продуктів ферментації та видалення шламу 3 нижньої частини, субстрат повинен мати допустимий нижній вміст дисперсної фази $m_{\partial}$. Цілком очевидно, що якісні параметри продуктів ферментації, які надходять у метантенк, також повинні бути в межах оптимальності, тобто $m_{\text {on }}$ $m_{\partial}$. Частота перемішування залежить від швидкості осідання зважених частинок субстрату.

У літературних джерелах $[1,7]$ подаються лише однозначні дані про оптимальний вміст сухої речовини в продуктах ферментації. Для визначення інших параметрів було проведено досліди з визначення фракційного складу гноївки. За результатами досліджень визначено еквівалентний діаметр частинок субстрату:

$$
\frac{1}{d_{e}}=\sum \frac{P_{i}}{d_{i}},
$$

де $d_{i}$ - діаметр частинок $i$-ої фракції субстрату; $P_{i}$ - відносний вміст фракції.

У результаті розрахунків отримано: $d_{e}=0,568 \pm 0,06 \mathrm{Mм}$.

Швидкість осадження частинок $v$ в субстраті при об'ємній його концентрації $1-m$, можна визначити за формулою [5]:

$$
v=\vartheta\left[k(1-m)+\sqrt{k^{2}(1-m)^{2}+m^{3}}\right], \quad \text { ь }
$$

де $m$ - відносний вміст дисперсного середовища субстрату; $\vartheta-$ швидкість вільного осідання частинок, мм/с.

Значення коефіцієнту $k$ визначається за формулою:

$$
k=\frac{3 \cdot \pi \cdot N}{R_{e} \cdot \eta_{r}} ;
$$

де $N$ - коефіцієнт фільтрації через шар осаду; $R_{e}$ - число Рейнольдса для вільного осідання частинок; $\eta_{r}-$ коефіцієнт опору вільного осідання частинок. 
Об'ємна концентрація субстрату $1-m$ залежить від концентрації частинок у вхідній порції субстрату $1-m_{6}$, яка подається в метантенк, та від його швидкості наповнення. При рівномірній подачі субстрату концентрація частинок в ньому по всьому об’єму буде приблизно однакова. Тоді частка дисперсної фази в стовпці висотою $h \cdot t$ дорівнюватиме $h \cdot t \cdot(1-m)$ і відрізняється від частки дисперсної фази субстрату, який подається метантенк $h \cdot t \cdot\left(1-m_{\varepsilon}\right)$ на величину $\vartheta \cdot t \cdot(1-m)$. У наведених виразах $h$ - швидкість росту стовпця сировини в метантенк, мм/с; $t$ - час надходження порції субстрату, с.

Звідси отримаємо:

$$
1-m=\left(1-m_{\partial}\right) \cdot \frac{h}{h+\vartheta} .
$$

В результаті перемішування отримаємо субстрат 3 оптимальним вмістом дисперсної фази $m_{\text {оn }}$ у всьому об’єму метантенка, забезпечивши оптимальне значення завантаження площі зброджування. Швидкість надходження порції субстрату можна визначити за формулою:

$$
h=\vartheta \frac{1-m_{o n}}{m_{6}-m_{o n}} .
$$

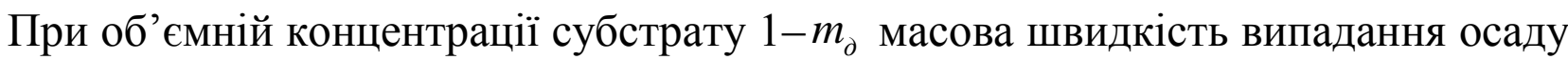
буде найбільшою:

$$
v=\left(1-m_{\partial}\right) \vartheta \frac{2-\alpha}{1-\alpha},
$$

де $\alpha$ - пористість осаду продуктів ферментації, $\alpha=0,2$ і не залежить від вологості.

Швидкість осідання частинок у воді становить $\vartheta=2,83 \mathrm{~mm} / \mathrm{c}$, а число Рейнольдса $R_{e}=1$ і $k=4,2 \div 4,5$ [5]. За формулою (6) визначено швидкість осідання частинок в субстраті при його об'ємній концентрації $1-m_{\partial}, v=1,275$ мм/с.

Визначимо допустимий відносний вміст дисперсного середовища $m_{d}$, при якому навантаження площі зброджування в метантенку буде не менше нижньої межі оптимальності: 
"Енергетика і автоматика", №4, 2019 р.

$$
m_{\partial}=1-\frac{\vartheta(1-\alpha)}{v(2-\alpha)} .
$$

Підставивши у вираз (7) значення параметрів продуктів ферментації отримаємо $m_{\partial}=0,0135$, тобто мінімально допустима кількість сухої речовини в $1 \mathrm{~m}^{3}$ субстрату повинна бути не менше 1,35 кг.

Час, за який відносний вміст дисперсної фази субстрату змінюватиметься від $m_{\text {on }}$ до $m_{\partial}$, $\epsilon$ часом пауз між циклами перемішування субстрату, що дозволить зменшити затрати енергії на виробництво біогазу.

Висновки і перспективи. Запропоновано методику визначення якісних показників продуктів ферментації біогазових установок. Підтримання їх в межах оптимальності дозволить підвищити продуктивність метантенка на 10-12 \%.

Урахування тривалості пауз у процесі перемішування продуктів ферментації дозволить зменшити затрати енергії на власні потреби біогазових установок.

\section{Список літератури}

1. Баадер В. Биогаз: теория и практика / В. Баадер, Е. Доне, М. Бренндерфер М. - М.: Колос, 1982. - 148 с.

2. Баротфи Н. Энергосберегающие технологии и агрегаты на животноводческих фермах / Н. Баротфи, П. Рафаи. - М.: Агропромиздат, 1988. - 227c.

3. Гюнтер Л. И. Метантенки / Л. И. Гюнтер, Л. Л. Гольдфраб - М.: Строй-издат, 1991. - $128 \mathrm{c}$

4. Корчемний М. О. Енергозбереження в агропромисловому комплексі / М. О. Корчемний, В. С. Федорейко, В. П. Щербань - Тернопіль: "Підручники і посібники", 2001. - 984 c.

5. Минц Д. М. Гидравлика зернистых материалов /Д. М. Минц, С. А. Шуберт М.: Стойиздат, 1985 - 443 с.

6. Семененко И. В. Проэктирование биогазовых установок / И. В. Семененко Суми: П «МакДон», ИПП «Мрия-1» ЛТД, 1996 - 347 с.

7. Стребков, Д. С. Биогазовые установки для обработки отходов животноводства / Д. С. Стребков, А. А. Ковалев // Техника и оборудование для села. - 2006. - №11. - С. 28-30

\section{References}

1. Baader, V., Done, E., Brennderfer, M. (1982). Biogaz: teoriya i praktika [Biogas: theory and practice]. Moskow: Kolos, 148. 
2. Barotfi, N., Rafai, P. (1988). Energosberegayushchiye tekhnologii i agregaty na zhivotnovodcheskikh fermakh [Energy saving technologies and units on livestock farms]. Moskow: Agropromizdat, 227.

3. Gyunter, L. I., Gol'dfrab, L. L. (1991). Metantenki [Digesters]. Moskow: Stroyizdat, 128.

4. Korchemnyi, M. O., Fedoreiko, V. S., Shcherban V. P. (2001). Enerhozberezhennia $\mathrm{v}$ ahropromyslovomu kompleksi [Energy conservation in agriculture]. Ternopil: Pidruchnyky i posibnyky, 984.

5. Mints, D. M., Shubert, S. A. (1985). Gidravlika zernistykh materialov [Hydraulics of granular materials]. Moskow: Stroyizdat, 443.

6. Semenenko, I. V. (1996). Proyektirovaniye biogazovykh ustanovok. [Planning of biogas options]. Sumi: P «MakDon», IPP «Mriya-1» LTD, 347.

7. Strebkov, D. S., Kovalev, A. A. (2006). Biogazovyye ustanovki dlya obrabotki otkhodov zhivotnovodstva [Biogas installations for processing of waste of livestock production]. Tekhnika i oborudovaniye dlya sela, 11, 28-30.

\section{МЕТОДИКА ОПРЕДЕЛЕНИЯ КАЧЕСТВЕННЫХ ПОКАЗАТЕЛЕЙ ПРОДУКТОВ ФЕРМЕНТАЦИИ БИОГАЗОВЫХ УСТАНОВОК}

\section{Н.В. Потапенко, В .Ю. Рами, В. Л. Шаршонь}

Аннотация. Повышение эффективности биогазовой установки определяется подбором компонентов по однородности и степени предварительного их измельчения, что влияет на количество полученного биогаза через длительность периода сбраживания.

Чтобы определить качественные характеристики продуктов ферментачии, применен метод отбора проб и выделения из них твердой фракиии.

Технологический прочесс получения биогаза нужно проводить таким образом, чтобы в результате перемешивания субстрата $c$ новой пориией, которая поступает в метантенк, получить продукт ферментачии $c$ оптимальным содержсанием дисперсной фазы. Частота перемешивания будет зависеть от скорости оседания взвешенных частии субстрата.

Проведень исследования по определению фракиионного состава навоза. По их результатам установлено эквивалентный диаметр частии субстрата. Определено допустимое относительное содержание дисперсной среды $m_{\partial}$, при котором нагрузка площади сбраживания в метантенку будет не меньше нижней границы оптимальности.

Поддержание качественных показателей продуктов ферментации в пределах оптимальности позволит повысить производительность метантенка на 10-12\%. Время, за которое относительное содержание дисперсной фазы субстрата будет меняться от $m_{\text {оп }}$ до $m_{\text {д }}$, представляет собой время пауз между ииклами перемешивания субстрата, что позволит уменьшить затраты энергии на производство биогаза.

Ключевые слова: анаэробная ферментация, метантенк, биогазовая установка, частота перемешивания, объемная концентрация субстрата 


\title{
TECHNIQUE OF DETERMINING THE QUALITATIVE INDICATORS OF THE PRODUCTS OF FERMENTATION OF BIOGAS INSTALLATIONS
}

\author{
M. Potapenko, V. Ramsh, V. Sharshon
}

Abstract. Improving the efficiency of a biogas plant is determined by the selection of components for uniformity and the degree of their preliminary grinding, which affects the amount of biogas obtained through the duration of the fermentation period.

To determine the qualitative characteristics of the products of fermentation, the method of sampling and extraction of the solid fraction from them is applied.

Technological process of receiving biogas needs to be carried out so that as a result of hashing of substrate with a new portion which arrives in digester, to receive a fermentation product with the optimum maintenance of a disperse phase. Frequency of hashing will depend on the speed of sedimentation of suspended particles of substrate.

Researches on determination of fractional composition of manure are conducted. ccording to their results, the equivalent particle diameter of the substrate was established. The permissible relative content of the dispersed medium was determined $m_{d}$, at which the load of the fermentation area in the digester would be no less than the lower limit of optimality.

Maintaining the quality indicators of fermentation products within the limits of optimality will allow to increase the performance of the digester by 10-12\%. The time for which the relative content of the dispersed phase of the substrate will vary from $m_{o p}$ to $m_{d}$, represents the time of pauses between the cycles of mixing of the substrate, which will reduce the energy costs of biogas production.

Key words: anaerobic fermentation, digester, biogas installation, mixing frequency, volume concentration of substrate 